UDC 371

N. Kuzmenko, Dr. of Pedagogical Sci., Assoc. Prof. Taras Shevchenko National University of Kyiv, Kyiv, Ukraine

\title{
PROBLEM OF TEACHER'S SELF-EDUCATION IN THE PEDAGOGICAL HERITAGE OF Ya. CHEPIHA
}

\begin{abstract}
The article is devoted to the scientific and practical analysis of the pedagogical heritage of Ukrainian teacher Yakov Chepiha with the aim of actualization for modern education. Ya. Chepiha was author of textbooks and manuals for primary school, and he had project for national school, a number of articles on the activities of the school, and teachers. The article analyzed pedagogical activity and pedagogical ideas of the famous Ukrainian teacher Ya. Chepiha. The article of the scientist "self-Education of the teacher" (1913), in which the author in depth described the qualities that should form teacher of Ukrainian school: reasoning, justice, patience, love for children, national understanding of child and the national self-education of the teacher, was conscious to thorough study. Relevance of the scientist's ideas for the modern Ukrainian school have been determined.
\end{abstract}

Key words: national school, education, self-education, Yakiv Chepiha.

Formulation of the problem. In conditions of reforming and improving the national education system is relevant a study and introduction into scientific circulation of the pedagogical heritage of outstanding countrymen. They devoted their lives on development of pedagogical science and teaching practice. Ya. Chepiha $(1875-1938)$ belongs to the cohort of the famous Ukrainian teachers of the second half of XX beginning of $X X I$ century. The pedagogical heritage of Ya. Chepiga requires a thorough study, analysis and use for preservation of domestic traditions today. Ukraine is entry into the world educational space. Yakiv Feofanovych Chepiha (Zelenkevych) (born. May 12, 1875, Maryanka, Kherson province, Russian Empire - August 22, 1938) was a Ukrainian educator, psychologist, social activist, author of the project of the Ukrainian school, the Ukrainian school books, over 150 scientific studies on the theory and methodology of primary education, whose ideas influenced the development of pedagogical science in Ukraine in the 1920-1930.

Analysis of recent researches. The heritage of Yakova Feofanovycha Chepihy is large and multidisciplinary and is the object of study of many scientists. In particular, researchers ZH. Ilchenko and I. Zaichenko studied the concept of the Ukrainian national school, L. Nikolenko studied the theoretical basis of education and training of junior schoolchildren, S. Yavorskaya studied the methodological principles in the pedagogical heritage of Ya. Chepigy. A lot of scientific research are devoted to scientific and pedagogical activities Ya. Chepiga (L. Berezovskaya, S. Boltyvets, V. Marochko, R. Paliychuk, A. Suhomlinskaia and so on.)

The purpose of the article is to analyze the pedagogical heritage of Ya. Chepihy, in particular his ideas about selfimprovement of the teacher.

Study presentation. Ukrainian educational specialist Ya. Chepiha came from an ancient Cossack family (his father - Zelenkevych, mother - Chepiha). He worked as a teacher, a lecturer, actively took in organizational and pedagogical work. In 1920-1925 - took part in the work of the organizing Committee in establishment of the Kiev Institute of public education (KINO). Later he received the post of Dean of the preschool faculty and associate dean. Than he worked as a Dean of the faculty of social education, Vicerector and Professor, he was one of the founders of the Kiev Pedagogical Institute in 1921. At first, he was the Vice-rector. Later he was research worker of the Department "Physical labor and work flows". In 1922 the Institute transformed into the Scientific-research Department of Pedology and Yakiv Feofanovych appointed head of the section of practical training, in which he worked until 1925. In the October 1925, he headed the section of methodology and didactic of the Kharkiv scientific-research Department of pedagogy. In the 1926 Ukrainian research Institute of pedagogy (UNDP) founded, where he worked as a researcher of the section of methods of teaching adults in 1933. In the October 1937 Ya. Cepiha arrested on charges of connection in anti-Soviet Ukrainian nationalist and terrorist organization and sentenced to 10 years of exile. On August 22, 1938, he died in exile, and he buried in the Magadan region of the Russian Federation. On March 20, 1958, by decision of the military Tribunal of the Kiev military district, the affair of Ya. F. Chepihy dismissed for lack of corpus delict [1].

Ya. Chepiga engaged in productive scientific and pedagogical work. Scientific writings devoted to the problems of pedagogy, didactic, theory of education, methods of teaching each disciplines. A significant part of his works Ya. Chepiha printed on the pages of newspapers "Svet", "Vchytel", "Pedahohichnyi zhurnal", "Ukraiinska hata", "Vilna Ukraiinska Shkola", "Shliash osvity" etc., using the assumed names: Ya. S., Ya. CH., S-vych, Buchytskyi, Sadovnyk, Teacher Ya, Chepiha etc. He was author of textbooks for primary school, textbook of methods for teachers, books for infant schools and children's libraries [2].

Pedagogue paid much attention to the development of Ukrainian education, creation of a national school in the conditions of anti-Ukrainian policy of the Russian government; noted the need to build a new system of education and upbringing, based on the study of the character of the child ("Attention and mental development", 1911; "Mendacity in education", 1912; "Fear and punishment", 1912). According to Ya. Chepiha, the Ukrainian school should be national, state and free ("Fundamental principles of normal school", 1911). In the "Project of Ukrainian school", published in 1913, Ya. Chepiha formed the requirements for the new Ukrainian school. The same year, Ya. Chepiha published his works "Problems of education and training" (1913), which sets out the views of the pedagogue on the problems of education: mental, physical, moral, labor, family and national. According to the scientist, national education is a vital need of the nation and the basis of such education is the family and school ("Nationality and national school", 1910). He has always taken care of the education and development of Ukrainian child on the national basis and created a number of textbooks from the Ukrainian language. Of great importance Ya. Chepiha in the creation of a new Ukrainian school provided the activities of teachers and his views on the quality of the teacher described in the article "self-study of teacher", which was published in the magazine "Svitlo" (1913).

The author identifies several opinions, the most important qualities of the personal, on the improvement of which teachers must constantly work namely: argumentation and work in activities, justice, kindness (goodness Ya. Chepiha), patience, love for children, national understanding of the child and the national self-education of the teacher. Ya. Chepiha believed that the teacher had also a cultural force that brings light and knowledge to people. His 
personality and behavior are model for children and adults. During the activities the teacher should inculcate in the younger generation the moral convictions of merit. That is why teachers have a great responsibility before the people. A teacher needs to improve, develop, grow in scientific and methodological targets.

According to the scientist, the first factors of improvement of each person are reasoning and work. Ya.Chepiha convinced that just to impact dry knowledge to the child was not enough. It is necessary to instill in the child universal values, all the best that a person has. Summing up this idea, the teacher noted:" to be a real example for others, it is necessary that the teacher reaches the height of universal virtues, incessant work brought himself up, upgraded and improved his abilities and developed his own character and will" [2, p. 10]. He believed that the teacher should be able to master their emotions and thoughts, because his work is full of surprises that need to controlle and thought about. According to Ya. Chepiha, reasoning and actions go side by side in their development and some without others lose their strength and importance in the improvement of person.

The scientist focused on the constant self-education of the teacher. Ya. Chepiha noted that constant work on yourself cleanses the soul and heart, thus contributes to the education of the teacher qualities such as justice, goodness, patience, love. They, according to the scientist, tells of the way in achieving the goals and tasks of this pedagogy. Each step the teacher must carefully consider and think over, so that no mistake. The teacher should always predict the consequences of his behavior, his words and actions.

Sense of justice for Yakov Feofanovich was an important moral force of the school life of the teacher. He says that the teacher needs to develop "mental hearing to other people's experiences, to understand the suffering of others" [7, p. 11]. In his opinion, is the first stage of moral improvement. The main thing is not to do to others what we do not want to do to us. The scientist points to the main rules of the teacher in working with children: "do not injure children" and "be justice to children in your work". Only under such conditions of selfeducation the teacher will reach the universal ideal of equity, which is so necessary for him. Ya. Chepiha gave the following definition: "justice is a virtue, which is based on a child goodness in school. It is inherent to person" [7, p. 12] and it doesn't warned to mix with civil servant or official justice, which was suitable for "enforce the last order". Ya. Chepiha believed that the teacher of reasoning and observation will help the teacher to find the true motive of the child's action. This will help him to be fair in his work. Ya. Chepiha spoke about truth in the work of the teacher: "When you want to give children satisfaction, pleasure and happiness, be fair to them, develop a sensitivity to their suffering, to grief, to their feelings. Bring attention to small human beings, to avoid labor actions, which will have at least a hint of a lie and dissatisfaction" [7, p. 16].

A special place in the self-education of the teacher Ya. Chepiha takes kindness. He saed that "Nothing disposes children to the teacher, how his sincere heart the goodness" [7, p. 17]. But emotions sometimes get the upper hand mind and, so, goodness yields to anger. Ya. Chepiha considered emotions an enemy of mind. Teacher (and indeed human) need to have greater will-power that such moments of emotional irritation to hold out and don't to violate their moral beliefs. According to Ya. Chepiha the best medicine is understanding and acknowledgement of his mistakes by the teacher. The scientist's statement that the face of the teacher is too high for the child is relevant. The explosion of evil feelings in it negatively affects the child and imparts to bad habits for life. A goodness of the teacher has a very positive influence on the formation of the moral views and beliefs of the child. Instilling in the child a kindness, we pave' the way to higher virtues" [2, p. 20]. Relevant today is the opinion of the teacher that "kindness creates a miracle:a few people speak, sad, entertaining, talkative, silent, sluggish - lively" [2, p. 21]. So, kindness is one of the virtues that fills the teacher with peace of mind. It is contributing to a positive atmosphere in the classroom, school and makes happy and joyful children's school years.

The teacher's virtue is no less important patience the virtue that relieves anger, longing, melancholy, and boredom according to Ya. Chepiha. About the same time Ya. Chepiha says all the "Self-teacher". It is patience that helps and facilitates the work of the teacher. It draws a parallel in the education and upbringing of children with a tree. A tree can slowly and patiently bent to the ground, give the desired direction and it will not break. We can tilt at once-and the tree would break. Yakov Feofanovich calls teachers: "they don't to maim children. He said that we would less experience by us for our actions. We would learn reserve, respect for children's actions and attentiveness and most importantly - patience in our actions and requirements" [7, p. 25].

Along with kindness, fairness and patience in dealing with schoolchildren Ya. Chepiha attached the high-profile to the love of children. He advises teachers to bring up in themselves tenderness of feeling and sensitivity to the child. He encourages teachers to love children sincerely. Scientist is convincing that only a sincere love can develop in the souls of children grain of good human feelings. "breeding with love and kindness of the teachers, the children freely and rapidly go the way of moral perfection" [7, p. 28]. The teacher called love for the child ideological and pure, that makes you think about others, take care of their well-being and bring peace and peace of mind. "...we save the integrity and purity of human nature in the child only reasonable and sincere love" [2, p. 28]. He addresses to teachers to develop love, soften the heart, to place his soul to the personality of the child, to bring up the heart and sensitivity to the child, to their grief and gladness. The opinion of the teacher that love for a child will at least partly cover the grave sin of indifference of citizenship and the state to the moral education of the younger generation is relevant today. Mentioned as a teacher of virtue: kindness, patience and love are intertwined, permeating each other. Therefore, in our opinion, the teacher must educate himself in the basic human values: Truth, Goodness and Beauty, which are unchanged and lean on them in their activities.

Finally, in his work, Ya. Chepiga violates the super important and today the issue of national self-teacher and national understanding of the child. He points to centuries of spiritual heritage send to the child the potential power of national energy. The child is inseparable from the influence of this power on the structure of her life. The teacher taking the child to school, must reckon with her nationality, because they do not take into account the national peculiarities. In a opinion of $\mathrm{Ya}$. Chepiha that instill in her alien, non-native, incomprehensible and give it a big upset. "The consequences of such training will be too obvious. People disappear for the nation and will not be good for humanity, for the death of the fruitful branch. It teared away from mother's tree and grafted into another, non-native root" $[7$, p. 30]. A special place is given to Ya. Chepiha role of teachers in the national education of the child. He calls the teacher a craftsman and laborer who does not know the people among whom he works, does not know his life, his moral credo. Faithful son of the Ukrainian people, Ya. Chepiha noted in his work, the teacher must be of the same nationality with the child. They reared in the same native soil with her or to adopt to the culture, language, national ideals of the people 
whose children he should teach. Thus, the teacher should be practiced by self-education with a deep understanding of all national marks a child he is teaching. The statement of the teacher that the fate of the Ukrainian people entrusted to the shoulders of the teacher. He must his true son, to connect himself with his past, to become conscious in the modern and to work for the future so that the children of the people were native to him in spirit, persuasions and ideals.

The scientist emphasizes that a child who grows up in the environment of his native language, native culture, absorbing ready moral images, later in adult life is keep to the beaten track of national beliefs, which stay in it for life. Spiritual acquisitions have been produced for centuries have the potential power of national energy. According to the scientist spiritual acquisitions are transmitted to the child. Of course, the language of the child adopts the culture of his native people, worldview, morality. Mention that the native language is the language of culture, in the context of which a child is brought up. The native language can be found, lost, changed or never change. There is a native culture, a native language. There is no native culture language of communication. From the point of view of science, Y. Chepiha approached the definition of the phenomenon of language: "Language of people as a psychophysical act has all the signs of nationality. Each word and even some individual sounds given a specific content, combined with certain ideas. Each nation have special national features love, kindness, truth and so forth" [2, p. 30]. We see in the early twentieth century, Ya. Chepiha began to talk about the connection of the word, its value and idea. At the end of the twentieth century it was spread and in-depth study in the form of concepts, words-signs of national culture. In the face of the teacher he saw the "culture bearer". He will give it people when the national body of the people will be the basis of his activities.

The opinion of the scientist is relevant, preserving the nationality of child - teacher retains her spiritual creative powers. It is very important, according to the teacher-scientist, "that the school had a teacher person of the same nationality with the child, brought up on native soil with her. Those who against their will have to teach in a foreign school, must take culture, language, national values of the people whose children they have to teach" [2, p. 33]. Therefore, for the teacher from Ukraine is necessary a national self-education, according to Ya. Chepiga.

Conclusions. Thus, Ya. Chepiha's article "Teacher selfeducation", analyzed and published in the journal "Svitlo" more than a hundred years ago. It is raises very important problems of modern school, the issues of professional training of teachers. The pedagogical ideas of Ya. Chepiha have not lost their importance, and his advice will be useful for young teachers and experience teachers.

\section{References}

1. Malovidomi dzherela $z$ ukrainskoi pedahohiky(druha polovyna KhIKh KhKh st.): khrestomatiia. / Uporiad.: L. D. Bezezivska.- Kyiv: Naukovyi svit, 2003. - S. 187-189

2.Ukrainska pedahohika v personaliiakh: u $2 \mathrm{kn}$. / za red. O. V. Sukhomlynskoi. Kn. 2.: KhKh stolittia. - Kyiv: "Lybid", 2005. - S. 89-99.

3.Chepiha Ya. F. Uvaha i rozumovyi rozvytok dytyny // Svitlo. - 1911. Kn. 1. - S. 20-33

4.Chepiha Ya. F. Brekhlyvist u spravi vykhovannia // Svitlo. - 1912. Kn. - S. 3-15

5.Chepiha Ya. F. Narodnii uchytel i natsionalne pytannia // Svitlo. - 1912. Kn. 1. - S. 15-25.

6. Chepiha Ya. F. Proekt ukrainskoi shkoly. Gruntovi postuliaty proekta // Svitlo. - 1913. - Kn. - S. 31-41

7.Chepiha Ya.F. Samovykhovannia vchytelia / Yakiv Feofanovych Chepiha. - K.: Ukrainska pedahohichna biblioteka, 1914-36 s.

Список використаних джерел

1. Маловідомі джерела 3 української педагогіки (друга половина XIX - XX ст.) : хрестоматія / упоряд.: Л. Д. Безезівська. - Київ : Наук. світ, 2003. - С. 187-189.

2. Українська педагогіка в персоналіях У 2 кн. / за ред. О.В. Сухомлинської. Кн. 2. ХХ століття. - Київ : Либідь, 2005. - С. 89-99.

3. Чепіга Я. Ф. Увага і розумовий розвиток дитини / Я. Ф. Чепіга // Світло, 1911. - Кн. 1. - С. 20-33.

4. Чепіга Я. Ф. Брехливість у справі виховання / Я. Ф. Чепіга // Світло. 1912. - Кн. - C. 3-15

5. Чепіга Я. Ф. Народній учитель і національне питання / Я. Ф. Чепіга // Світло. - 1912. - Кн. 1. - С. 15-25.

6. Чепіга Я. Ф. Проект української школи. Ґрунтові постуляти проекта / Я. Ф. Чепіга // Світло. - 1913. - Кн. - С. 31-41.

7. Чепіга Я.Ф. Самовиховання вчителя / Яків Феофанович Чепіга. - К. : Українська педагогічна бібліотека, 1914. - 36 с.

Надійша до редколегії 02.02.19

Н. Кузьменко, д-р пед. наук, доц.

Київський національний університет імені Тараса Шевченка, Київ, Україна

\section{ПРОБЛЕМА САМОВИХОВАННЯ ВЧИТЕЛЯ У ПЕДАГОГІЧНІЙ СПАДЩИНІ Я. ЧЕПІГИ}

Проаналізовано педагогічну діяльність і педагогічні ідеї відомого українського педагога Я.Ф. Чепіги (Зеленкевича). Наведено коротку біографічну довідку про життєвий шлях і професійну діяльність Я. Чепіги. Досліджено погляди педагога на питання розвитку української освіти, створення національної школи в умовах антиукраїнської політики російського уряду. Виокремлено праці Я. Чепіги, в яких він наголошував на необхідності побудови нової системи освіти і виховання, заснованої на вивченні природи дитини ("Увага і розумовий розвиток",1911 р.; "Брехливість у справі виховання", 1912 р.; "Страх і кара", 1912 р.), створенні національної, вільної школи ("Грунтовні принципи нормальної школи", 1911р.; "Проект української школи", 1913 р.), національного виховання ("Національність і національна школа", 1910 р.; "Проблеми виховання і навчання", 1913 р.). Визначено перелік періодичних видань, в яких були надруковані статmі Я. Чепіги (Світло", "Учитель", "Педагогический журнал", "Украинская хата", "Вільна Українська Школа", "Шлях освіти") під псевдонімами: Я.З., Я.Ч., 3-вич, Бучицький, Садовник, Учитель, Я. Чепіга та ін. Виняткову увагу приділено вивченню та ґрунтовному аналізу статті вченого "Самовиховання вчителя" (1913), у якій автор високо оцінює працю вчителя і його суспільну роль та скрупульозно характеризує якості, які має формувати вчитель української иколи: міркування, справедливість, терпіння, любов до дітей, національне розуміння дитини та національне самовиховання вчителя. Визначено актуальність ідей вченого для сучасної української школи. Я. Чепіга у своїй праці порушує надважливе на сьогодні питання національного самовиховання вчителя та національного розуміння дитини. Він зазначає, що століття духовного надбання передають дитині потенційну силу національної енергії і дитина невіддільна від впливу цісї сили на склад їі життя.

Ключові слова: національна школа, вчитель, виховання, національне виховання, самовиховання, Яків Чепіга. 